\title{
PARKI, OGRODY ORAZ INNE FORMY KOMPONOWANEJ ZIELENI - WARUNKI BRZEGOWE WSPÓŁCZESNYCH INTERWENCJI
}

SIKORA Dorota ${ }^{1}$

${ }^{1}$ dr inż. Dorota Sikora Katedra Sztuki Krajobrazu, Szkoła Główna Gospodarstwa Wiejskiego w Warszawie

https://orcid.org/0000-0002-7775-5722

ABSTRAKT: W artykule omówiono zasób polskich parków i ogrodów zabytkowych oraz stan ich zachowania. Podkreślono, że specyfika tej części dziedzictwa kulturowego wynika między innymi $z$ wysokiego udziału tworzywa roślinnego (materii żywej) oraz niskiej trwałości substancji zabytkowej. Scharakteryzowano najczęściej występujące zagrożenia oraz sformułowano podstawowe zasady i warunki brzegowe dla ochrony, konserwacji oraz adaptacji do nowych funkcji dla tej grupy zabytków. Wskazano, że zakres powyższych działań powinien wynikać z przepisów prawa oraz dokumentów doktrynalnych. Omawiane zagadnienia zilustrowano polskimi i zagranicznymi przykładami - zarówno pozytywnymi, jak i negatywnymi. W podsumowaniu artykułu określono obszary, w jakich należałoby w pierwszej kolejności wzmocnić działania na rzecz ochrony i konserwacji tej grupy zabytków.

SŁOWA KLUCZOWE: historyczne parki i ogrody, restauracja zabytków, ochrona zabytków 


\section{Dorota Sikora}

\section{Wstęp}

Zabytkowe parki i ogrody to ważny element dziedzictwa kulturowego. Stanowią cenny dokument kultury materialnej poprzednich stuleci, budują tożsamość polskiego pejzażu. Stwierdzenie to dotyczy zarówno wspaniałych założeń rezydencjonalnych, przekształconych w obiekty muzealne, jak i tych skromniejszych, dworsko-parkowych, coraz częściej odchodzących w zapomnienie, pozbawionych historycznej funkcji, a także publicznych parków miejskich, dynamicznie zmieniających się w związku z nowymi formami użytkowania wprowadzanymi w ich granice.

Parki i ogrody to grupa zabytków o niskiej trwałości - bez właściwej ochrony oraz prawidłowo prowadzonych działań z zakresu pielęgnacji, konserwacji, a niekiedy restauracji giną. Już na przełomie XVIII i XIX wieku, w dobie niesamowitego rozkwitu sztuki ogrodowej, Ignacy Krasicki przestrzegał: Gmachy z kamienia, cegły lub marmuru zrządzone, aczkolwiek czas pożera z ostatków pozostałych, iż były, a niekiedy jakie być mogły, domyślić się można. Ogrody, z istoty swojej dzieła ziemne, tego przywileju nie mają ${ }^{1}$.

2. Stan i specyfika zasobu zabytkowych parków, ogrodów i innych form projektowanej zieleni oraz wynikająca $\mathrm{z}$ nich potrzeba prowadzenia prac konserwatorskich, restauratorskich i działań adaptacyjnych

W Raporcie o Stanie Zabytków Nieruchomych ${ }^{2}$ opracowanym przez Narodowy Instytut Dziedzictwa (2017) stwierdzono, że obiekty zabytkowe sklasyfikowane jako „zieleń” to 10,51\% zasobu wszystkich zabytków w Polsce. Ich liczba (bez cmentarzy), według danych NID (stan na 1. Kwartał 2019 r.), wynosi 7623, z czego znaczącą większość - ponad 70\% - stanowią parki i ogrody rezydencjonalne.

Historyczne parki, ogrody oraz inne formy zaprojektowanej zieleni, jako jeden z typów obiektów zabytkowych, podlegają ochronie i opiece 3 . W praktyce nie zawsze tak się dzieje. W „Raporcie” NID (2017) 29,1\% zabytkowych terenów zieleni przyporządkowano do kategorii obiektów zachowanych w stanie średnim, a 8,8\% do kategorii obiektów zachowanych w stanie złym, co, jak stwierdzono, sytuuje te zabytki w grupie obiektów o wyraźnie obniżonym ogólnym stanie zachowania. Jednocześnie w „Raporcie” oceniono, że 50,7\% zabytkowych terenów zieleni znajduje się w stanie dobrym, a jedynie $11,5 \%$ w stanie bardzo dobrym ${ }^{4}$.

Cechą charakterystyczną zasobu parków, ogrodów oraz innych form zaprojektowanej zieleni jest ich niska trwałość. Zależy ona od trwałości elementów składowych, wśród których wiodącym jest roślinność. Longin Majdecki oceniał, że trwałość jednej generacji form roślinnych, tworzących

\footnotetext{
${ }^{1}$ Krasicki I., Listy o ogrodach, [w:] Dzieła proza Ignacego Krasickiego, edycja nowa $i$ zupetna przez Fr. Dmochowskiego, t. V. Warszawa, 1803.

${ }^{2}$ Rozbicka M. (red.), Raport o stanie zabytków nieruchomych w Polsce. Zabytki wpisane do rejestru zabytków (ksiegi rejestru A i C), Warszawa: Narodowy Instytut Dziedzictwa, 2017.

3 Ustawa z dnia 23 lipca 2003 r. o ochronie zabytków i opiece nad zabytkami, art. 6, Dz.U. 2003 nr 162 poz. 1568.

${ }^{4}$ Raport..., op. cit.
} 
układ przestrzenny ogrodu, wynosi około 100 lat ${ }^{5}$. Trwałość poszczególnych elementów składowych parków i ogrodów, takich jak partery, różanki, kwietniki, jest jeszcze niższa.

Zły lub średni stan zachowania znacznej części zasobu parków, ogrodów i innych form zaprojektowanej zieleni, przy ich niskiej trwałości, powoduje, że w wielu z nich występuje aktualnie pilna konieczność przeprowadzenia prac konserwatorskich lub restauratorskich, wiązanych często $\mathrm{z}$ adaptacją tych obiektów do nowych funkcji. W tej sytuacji konieczne jest dołożenie szczególnych starań, aby prace prowadzone w obiektach zieleni zabytkowej nie wpływały degradująco na ich substancję zabytkową. Powinny one uwzględniać regulacje prawne wynikające z ustawowych definicji pojęć „prac konserwatorskich” $i$ „prac restauratorskich” oraz zalecenia dokumentów doktrynalnych, w tym w szczególności Karty Weneckiej $(1964)^{6}$ oraz Karty Florenckiej (1981) 7 .

\section{Zasady ochrony oraz prowadzenia prac konserwatorskich i restauratorskich w obiektach zabytkowej zieleni w kontekście doktryny konserwatorskiej}

Punktem wyjścia do określenia zasad ochrony i konserwacji zabytkowych terenów zieleni powinno być stwierdzenie zawarte $\mathrm{w}$ definicji zabytku w Ustawie $\mathrm{z}$ dnia 23 lipca 2003 roku o ochronie zabytków i opiece nad zabytkami, że zabytek, a zatem i park zabytkowy, jest dziełem człowieka (art. 3) oraz że, zgodnie z definicją ogrodu zabytkowego z Karty Florenckiej (art. 1), jest to kompozycja architektoniczno-roślinna.

Powyższe stwierdzenia pozwalają na zróżnicowanie sposobu traktowania zabytkowych terenów zieleni oraz terenów zieleni naturalnego pochodzenia. Jest to niezwykle istotne w dzisiejszych czasach, kiedyze względów ekologicznych, społecznych oraz ekonomicznych dają sięzaobserwować tendencje do minimalizacji pielęgnacji terenów zieleni, w tym również tych zabytkowych. Niestety bez systematycznej pielęgnacji zabytkowy ogród nie ma szans na przetrwanie. Na obowiązek regularnego i stałego utrzymywania zabytków w należytym stanie zwrócono uwagę już w karcie ateńskiej w 1931 roku i podtrzymano to wskazanie w karcie weneckiej, gdzie stwierdzono, że: konserwacja zabytków zakłada przede wszystkim obowiązek ciągłości ich należytego utrzymania (Art. 4). W tym samym nurcie wypowiedzieli się eksperci w poświęconej ogrodom karcie florenckiej, wskazując, że: Utrzymywanie i konserwowanie ogrodu historycznego jest podstawową działalnością z natury rzeczy stałą (Art. 11).

Równie istotny, z punktu widzenia ochrony zabytków sztuki ogrodowej, jest sformułowany w karcie weneckiej obowiązek przyjęcia solidarnej odpowiedzialności za zachowanie [zabytków] dla przyszłych pokoleń i przekazania im ich wartości w całym bogactwie autentyzmu. Tak sformułowany cel ochrony zabytków, a zatem i obiektów zieleni zabytkowej, powoduje, że współczesne pokolenia nie mogą czuć się jedynymi właścicielami i użytkownikami zabytkowych terenów zieleni. Zgodnie

\footnotetext{
${ }^{5}$ Majdecki L., Ochrona i konserwacja zabytkowych założeń ogrodowych, Warszawa: PWN, 1993.

${ }^{6}$ Karta Wenecka-Postanowienia i Uchwały II Międzynarodowego Kongresu Architektów i Techników Zabytków w Wenecji w 1964 roku, 1964.

${ }^{7}$ Karta Florencka - Międzynarodowa Karta Ogrodów IFLA, ICOMOS, 1981.
} 
$\mathrm{z}$ duchem Karty Weneckiej jesteśmy przede wszystkim depozytariuszami zabytków, w tym zabytków sztuki ogrodowej, które mamy przekazać przyszłym pokoleniom w całym bogactwie ich autentyzmu.

Pojęcie autentyczności ogrodu zabytkowego definiuje Karta Florencka: Autentyczność ogrodu historycznego dotyczy w jednakiej mierze jego rysunku i wielkości poszczególnych jego części jak i dekoracji, wyboru roślin i minerałów, z których się składa (Art. 9). Zatem przedmiotem ochrony i szczególnej uwagi w trakcie prac konserwatorskich lub restauratorskich powinny być zarówno forma przestrzenna ogrodu, jego skala, elementy wystroju, dobór roślin oraz zastosowanych historycznie materiałów budowlanych. Stan wielu współczesnych parków i ogrodów zabytkowych jest dowodem na to, jak trudno jest te cechy utrzymać.

W karcie florenckiej wskazano, że sukces działań ochronnych (a także konserwacji i restauracji tej grupy zabytków) uzależniony jest od ich rozpoznania: ochrona ogrodów historycznych wymaga ich identyfikacji i inwentaryzacji (Art. 9). Rozpoznanie obiektu zabytkowego umożliwia określenie jego wartości, których ochrona lub ewentualne uczytelnienie powinny stanowić podstawowy cel działań w odniesieniu do zabytków, w tym również zabytków sztuki ogrodowej. Podstawową dokumentacją dla zabytkowych parków i ogrodów w Polsce są tzw. dokumentacje ewidencyjne. Niestety znacząca ich większość powstała w latach 70. i 80. XX wieku, co powoduje, że nie prezentują one obecnego stanu zabytków sztuki ogrodowej. Konieczna jest zatem ich pilna aktualizacja.

W karcie ateńskiej zwrócono również uwagę na konieczność dokumentowania wszelkich prac przy zabytkach: zarówno badawczych, konserwatorskich, jak i adaptacyjnych, aby w przyszłości można było odtworzyć historię ich przemian. Postulat ten powinien również dotyczyć zabytkowych terenów zieleni.

Międzynarodowe karty konserwatorskie poświęcają wiele uwagi zagadnieniom restauracji i rekonstrukcji zabytków. Restauracja zabytków jest jednym z działań zdefiniowanych w Ustawie z dnia 23 lipca 2003 roku o ochronie zabytków i opiece nad zabytkami. Są to działania mające na celu wyeksponowanie wartości artystycznych i estetycznych zabytku, w tym, jeżeli istnieje taka potrzeba, uzupełnienie lub odtworzenie jego części, oraz dokumentowanie tych działań (Art. 3). Jak wskazano w poprzednim podrozdziale, parki, ogrody i inne formy projektowanej zieleni to obiekty o niskiej trwałości, wymagające stałej pielęgnacji, okresowej konserwacji, a w przypadku wieloletnich zaniedban - restauracji z elementami uzupełnień i odtworzeń. Przekazywanie ich przyszłym pokoleniom „w całym bogactwie autentyzmu” jest niezwykle trudne, a działaniom w nich podejmowanym bliżej w praktyce do Dokumentu z Nara o autentyzmie (1994) niż do Karty Weneckiej. Restauracja parku zabytkowego powinna być oparta na naukowych podstawach, na co zwraca uwagę Karta Florencka (Art. 15), oraz nie może uprzywilejowywać żadnej z epok (Art. 16). Jak zauważono w karcie weneckiej, Ustaje ona [restauracja] tam, gdzie zaczyna się domysł (Art. 9).

${ }^{8}$ Jagiełlo M., Do We Need a New Florence Charter? The Importance of Authenticity for the Maintenance of Historic Gardens and Other Historic Greenery Layouts in the Context of Source Research (Past) and Taking into Account the Implementation of the Sustainable Development Idea (Future), Sustainability, 13(9), 4900, 2021, https:/doi.org/10.3390/ sul3094900 
W kartach konserwatorskich sformułowano też wiele zaleceń dotyczących relacji zabytku i jego otoczenia. Już w latach 30. XX wieku zauważono potrzebę ochrony szczególnie malowniczych widoków, co odzwierciedlają postanowienia Karty Ateńskiej. Na potrzebę ochrony kontekstu krajobrazowego zabytków zwraca też uwagę Karta Wenecka, w której wskazano, że konserwacja zabytku zakłada konserwację otoczenia w jego skali (Art. 6). Zasadę tę przywołano także w karcie florenckiej, podkreślając konieczność ochrony otoczenia parku zabytkowego nie tylko ze względu na wartości widokowe i kompozycyjne, ale również z powodu potrzeby ograniczenia potencjalnego negatywnego oddziaływania procesów zachodzących w tym otoczeniu na szatę roślinną (Art. 14).

Najtrudniejszymi do zachowania we współczesnych realiach wydają się być zalecenia Karty Florenckiej, dotyczące form użytkowania parków zabytkowych. Autorzy karty jako preferowany model wypoczynku wskazali wypoczynek bierny, przy równoczesnym pewnym ograniczeniu dostępności do tego typu obiektów. Rekreację czynną w ogrodach zabytkowych dopuszczono w karcie jedynie okazjonalnie, wskazując, że lepszym dla niej miejscem będą tereny poza ich granicami (Art. 18). Takie podejście do współczesnej funkcji zieleni zabytkowej wynikało z chęci kontynuacji funkcji historycznej, którą w przeważającej większości stanowił właśnie wypoczynek bierny (niekiedy z dopuszczoną na niewielkich fragmentach rekreacją czynną np. w postaci gry w tenisa), powiązany czasami z produkcją ogrodniczą i sadowniczą. Obiektem, gdzie do dziś udało się zachować podział na część przeznaczoną do zwiedzania i wypoczynku biernego od części, gdzie dopuszczono wypoczynek czynny jest na przykład Ogród Wersalski (Petit Parc, ogrody Petit Trianon i Grand Trianon - tylko zwiedzanie i spacery, Grand Parc - wypoczynek aktywny, jazda na rowerach, jogging, pływanie łódkami po kanale) $)^{9}$.

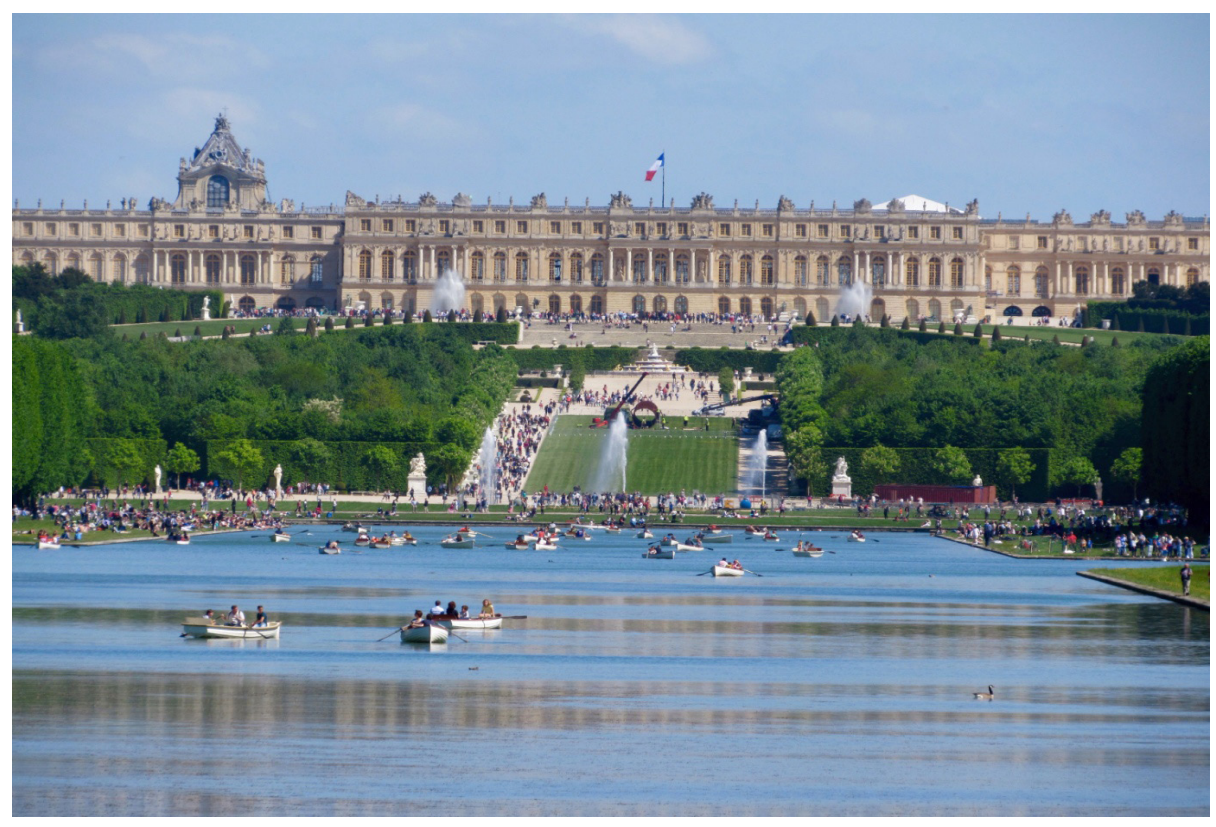

Il. 1. Czynny wypoczynek w granicach Grand Parc w Wersalu oraz turystyka jako dominująca forma rekreacji w Petit Parc. Fot. D. Sikora, 2018

${ }^{9}$ Sikora D., Nowe tendencje w obiektach zieleni zabytkowej - na przykładzie Ogrodu Wersalskiego, Teka Komisji Urbanistyki i Architektury PAN Oddział w Krakowie, t. XLV, 2017, ss. 525-539. 
Zmiany społeczne ostatnich kilkudziesięciu lat doprowadziły do zmiany modelu użytkowania zabytkowych terenów zieleni - zwłaszcza tych, które z obiektów prywatnych stały się publicznie dostępnymi. Ich historyczną formę trudno było pogodzić z nowymi funkcjami i oczekiwaniami użytkowników, szczególnie w przypadku zabytkowych terenów zieleni miejskiej. Jogging alejkami Łazienek Królewskich czy piknik na trawie w ogrodach Zamku Królewskiego w Warszawie nikogo już dziś nie dziwią.

\section{Problematyka zachowania autentyczności rozwiązań kompozycyjnych i materiałowych oraz kontekstu krajobrazowego zabytkowych parków, ogrodów oraz innych form zaprojektowanej zieleni}

Jak stwierdzono powyżej, parki i ogrody, również te zabytkowe, różnią się od naturalnych lasów i zadrzewień czy terenów łąkowych tym, że są dziełami człowieka. Dziełami człowieka są średniowieczny wirydarz, renesansowy ogród tarasowy, barokowe założenie pałacowo-ogrodowe, park krajobrazowy, ogród kaligraficzny, publiczny park miejski, ogród willowy, tereny zieleni towarzyszącej obiektom użyteczności publicznej i wiele innych. Ich wspólnym mianownikiem jest fakt, że nadano im ściśle określoną kompozycję, skalę, proporcje, wprowadzono elementy małej architektury i wystroju rzeźbiarskiego, zastosowano ściśle określony dobór roślin i materiałów budowlanych. Posiadają one zatem te wszystkie cechy, które według Karty Florenckiej decydują o ich autentyzmie (Art. 9).

Cechy te, $\mathrm{w}$ związku $\mathrm{z}$ różnego typu współczesnymi interwencjami, zarówno tymi natury budowlanej, jak i formalno-prawnej, mogą ulec zatarciu, co prowadzi do degradacji zabytkowego trenu zieleni. Należy również zauważyć, że dla parków brak ingerencji, polegający np. na zaprzestaniu pielęgnacji, jest równie groźny.

Autorka omawia poniżej wpływ współczesnych interwencji bądź ich braku na tę grupę zabytków na wybranych przykładach z Mazowsza, Podlasia i Pomorza, przywołując również przykłady zagraniczne.

Jak już zauważono, dla utrzymania czytelności kompozycji zabytkowego ogrodu czy parku niezwykle istotna jest ciągłość pielęgnacji. W dobie powojennych przemian politycznospołecznych na tę ciągłość mogło liczyć zaledwie kilka obiektów, które jeszcze w latach 40. otrzymały status muzealny. Były to pałace i ogrody w Łańcucie (1944), Kozłówce (1944), Wilanowie (1945), Natolinie (1945), Nieborowie (1945), Arkadii (1945) i Rogalinie (1949) ${ }^{10}$. W niektórych z nich, jak np. w Ogrodzie Wilanowskim, już wkrótce po zakończeniu działań wojennych rozpoczęto prace konserwatorskie.

\footnotetext{
${ }^{10}$ Michałowski A., Rewaloryzacja ogrodu Jana Klemensa Branickiego w Białymstoku na tle działań konserwatorskich w ogrodach historycznych Europy, [w:] Parki i ogrody zabytkowe, ochrona i konserwacja. Ogród Branickich w Bialymstoku, historia rewaloryzacji, Białystok: Urząd Miejski w Białymstoku, 2010, s. 172.
} 


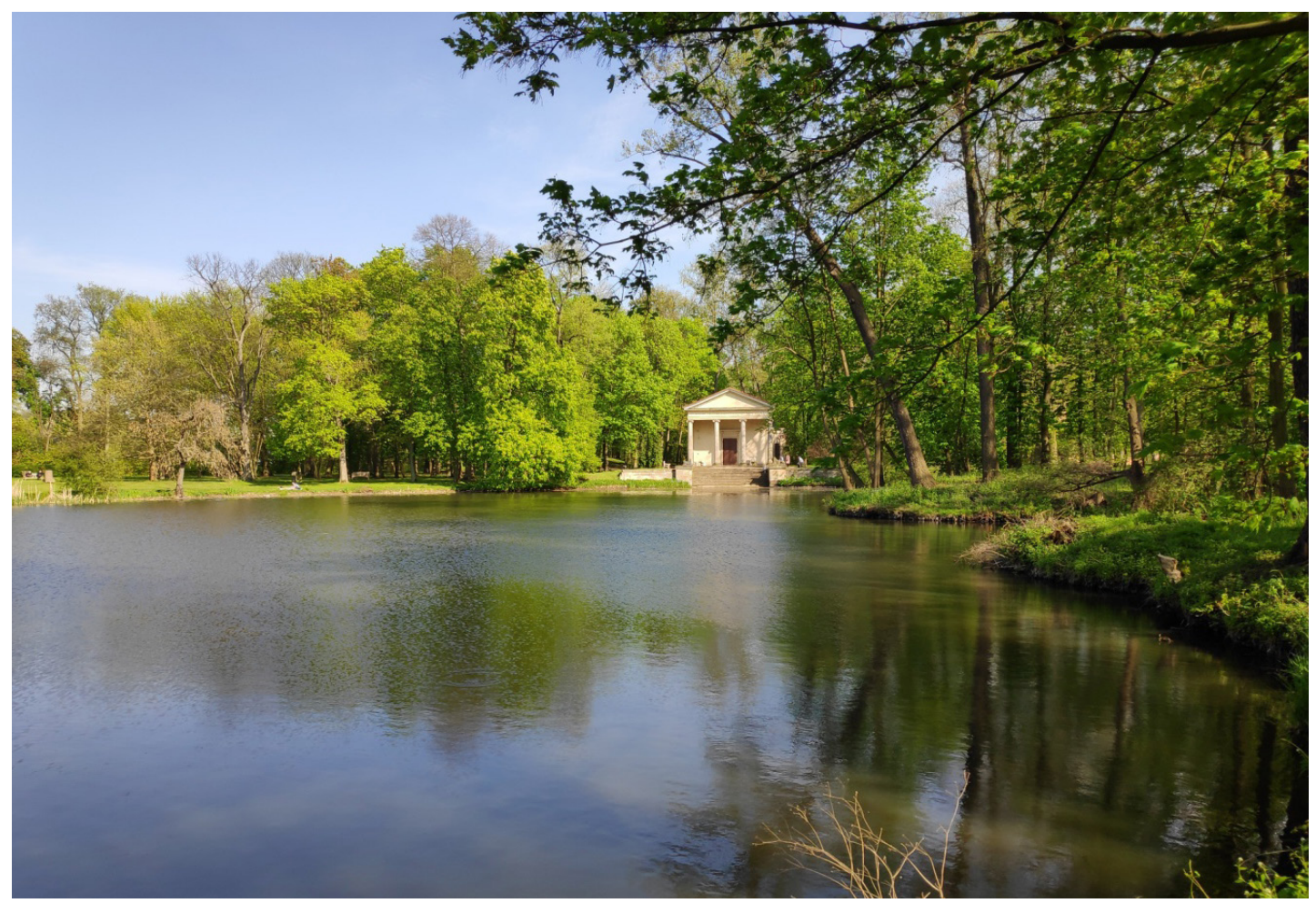

Il. 2. Arkadia - park uzyskał status muzealny w 1945 r., co sprzyjało zachowaniu ciągłości pielęgnacji, fot. D. Sikora, 2020

Pozostałe parki historyczne zostały po nacjonalizacji przejęte przez Państwowe Gospodarstwa Rolne, zakłady opiekuńcze, szkoły, szpitale, urzędy i inne instytucje publiczne. Wiązało się to ze zmianą sposobu ich użytkowania: z ogrodów rezydencjonalnych o ograniczonej dostępności przekształcono je w ogrody publiczne, dostępne dla znacznie większej liczby użytkowników, mających inne potrzeby i priorytety niż przedwojenni właściciele. Ich kompozycja ulegała deformacji - z powodu zaniedbań w pielęgnacji (np. Ślubowo, Poświętne, Celbowo, Lublewo Lęborskie, Neple, Konstantynów), wznoszenia nowych budynków szkolnych, przedszkoli, internatów (np. Żuromin, Stare Lubiejewo, Nacpolsk, Luberadz, Neple), wprowadzania zabudowy mieszkalnej dla pracowników Państwowych Gospodarstw Rolnych (Chamsk), boisk (Żuromin, Nacpolsk, Poświętne, Strzembowo).

W wyjątkowych sytuacjach, ale dotyczących również parków o dużych wartościach historycznych, artystycznych i naukowych, brak pielęgnacji powodowany jest objęciem ich ochroną w postaci rezerwatu przyrody. Dotyczy to między innymi tak cennych parków warszawskich jak Natolin, Ursynów (dawna Roskosz) oraz Morysin czy też podlaskiego Korczewa, gdzie połowę parku uznano za rezerwat przyrody. Plany ochrony utworzonych tam rezerwatów bardzo ograniczają możliwości prowadzenia jakichkolwiek prac pielęgnacyjnych. 


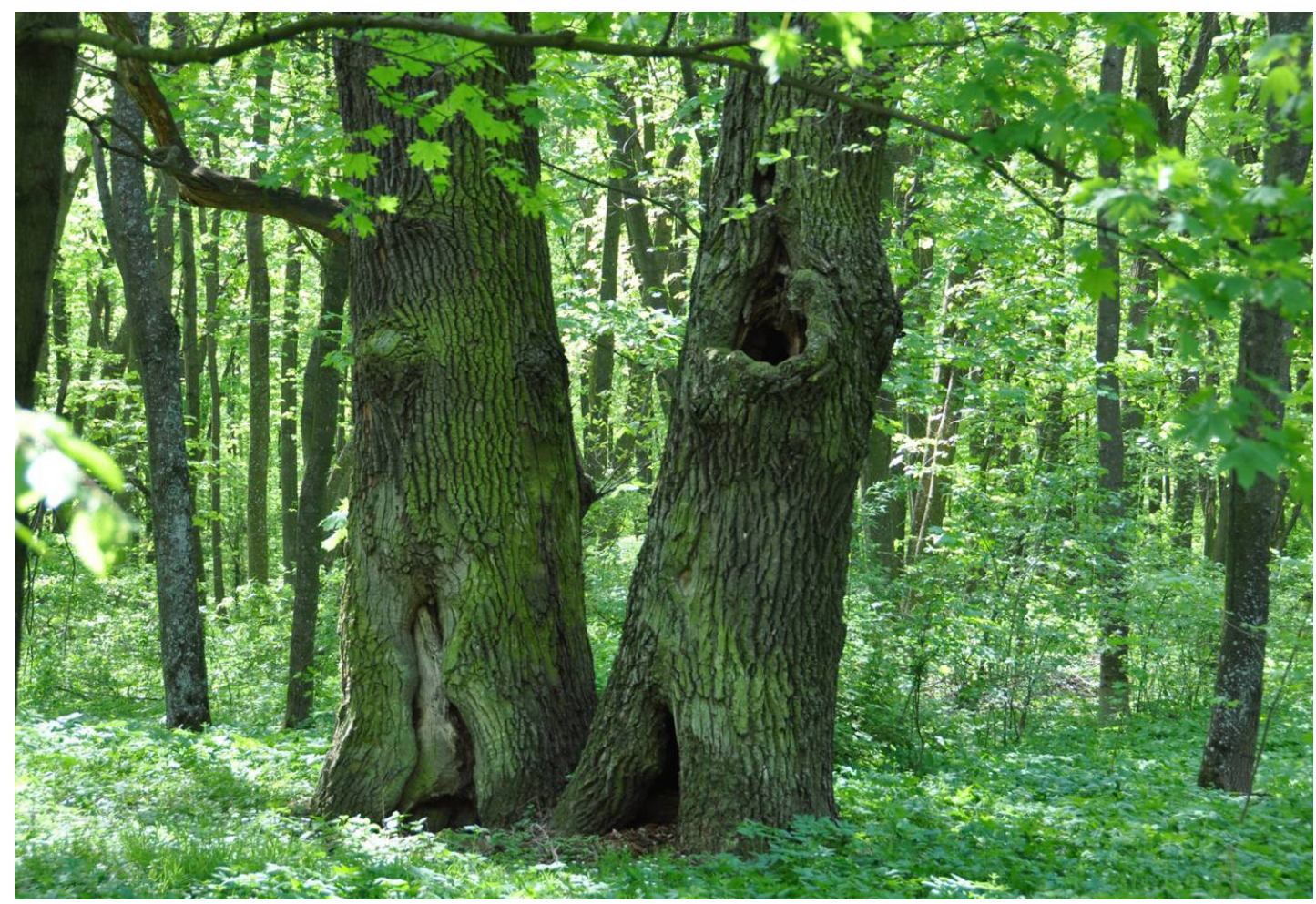

Il. 3 Fragment założenia pałacowo-ogrodowego w Korczewie - rezerwat „Dębniak”, którego utworzenie uniemożliwiło konserwację tej części parku. Fot. D. Sikora, 2019

Szczególnym przypadkiem degradacji kompozycji parku zabytkowego jest pozbawienie go głównej dominanty architektonicznej. Według danych Narodowego Instytutu Dziedzictwa liczba parków zabytkowych, w których przestała istnieć główna dominanta architektoniczna, to 1632 obiekty (25\%). Zjawisko to występuje głównie w województwach: zachodniopomorskim (57,32\% parków zabytkowych), śląskim (52,5\%), lubuskim (37,8\%), warmińsko-mazurskim $(35,0 \%)$, opolskim $(29,6 \%)$, podlaskim (26,2\%). Najbardziej znanym w Polsce przykładem tej sytuacji jest Ogród Saski w Warszawie. W niektórych parkach powojenne decyzje doprowadziły do zastąpienia historycznej dominanty pałacu zabudową współczesną. Można tu wskazać park pałacowy w Białowieży z Muzeum Przyrodniczo-Leśnym w miejscu rezydencji carskiej czy zabytkowe parki w Siemiatyczach i Piasecznie, gdzie w miejscu pałaców wzniesiono współczesne siedziby tamtejszych starostw powiatowych. Działania te przyczyniły się do obniżenia wartości autentyzmu i integralności historycznych kompozycji ogrodowych.

W parkach rezydencj onalnych funkcję siedziby mieszkalnej po zniszczeniu pałacu czy dworu niekiedy przejmowały inne historyczne budynki, co jest znacznie korzystniejszym rozwiązaniem z punktu widzenia integralności i autentyczności obiektu. Dobrym przykładem tego typu działań jest założenie parkowe w Starzyńskim Dworze na Pomorzu, gdzie jeden z obszernych budynków folwarcznych zaadaptowano do celów mieszkalnych. 


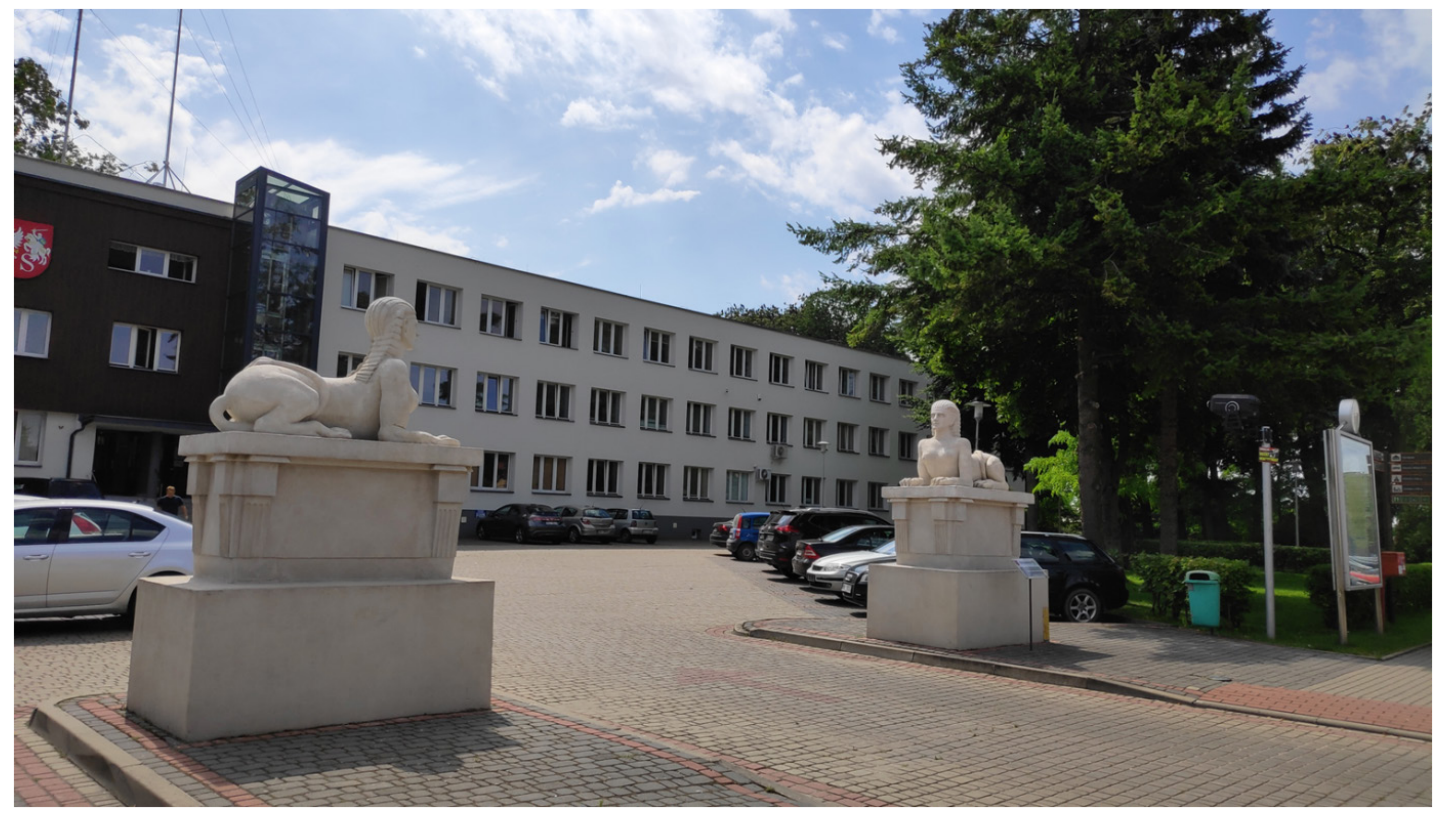

Il. 4. Współczesna siedziba Starostwa Powiatowego w Siemiatyczach w miejscu osiemnastowiecznego pałacu księżnej Anny Jabłonowskiej. Fot. D. Sikora, 2020

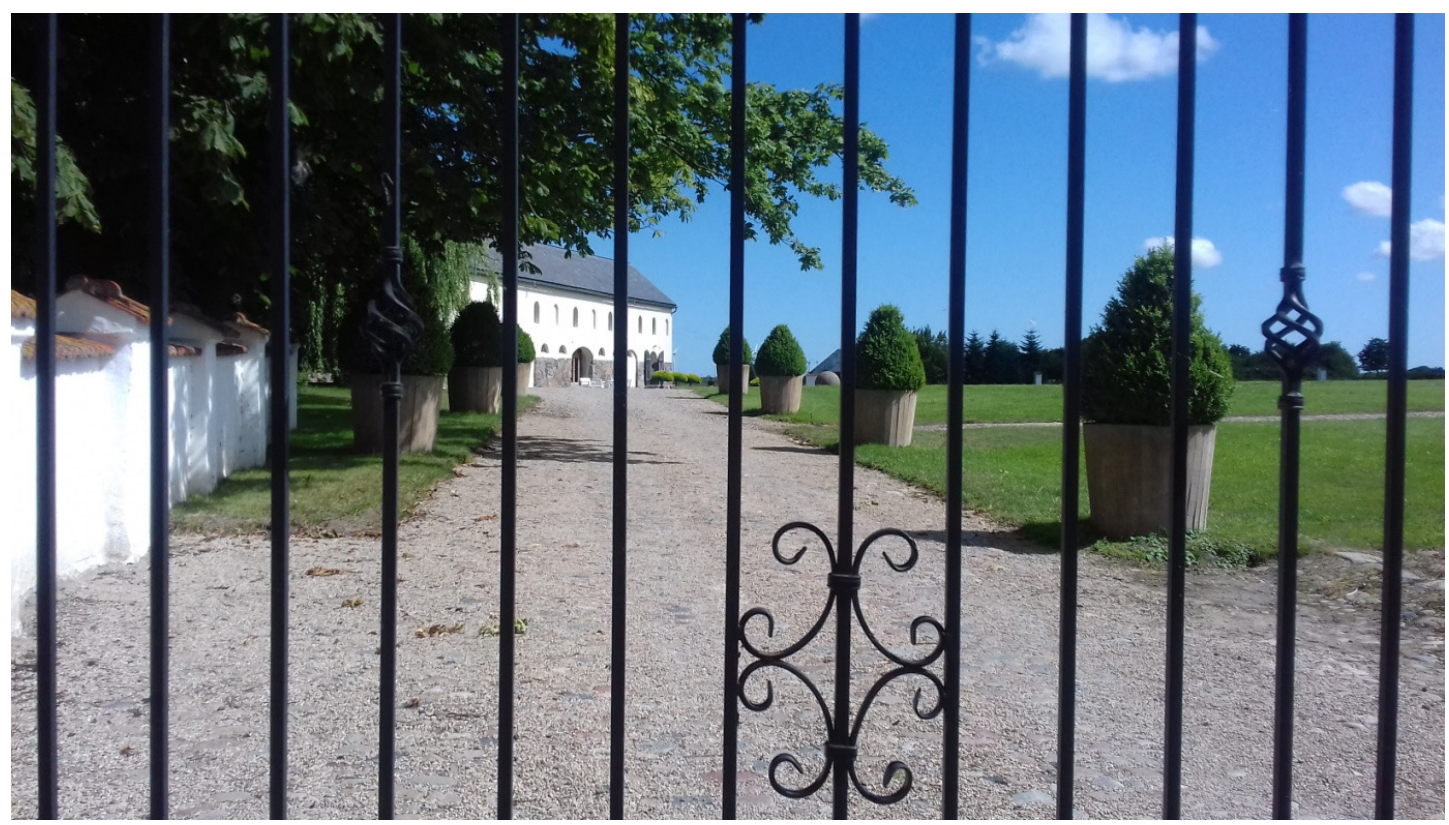

Il. 5. Park w Starzyńskim Dworze. Pałac uległ zniszczeniu w czasie II wojny światowej, a funkcję mieszkalną przejął jeden z budynków gospodarczych. Fot. D. Sikora, 2017 
Czynnikiem wpływającym degradująco na wartości autentyzmu i integralności zabytkowych terenów zieleni są również podziały własnościowe, utrudniające, a niekiedy wręcz uniemożliwiające prowadzenie spójnej polityki konserwatorskiej. Najczęściej podziały te były skutkiem wprowadzania w granice parku nowej funkcji. Z czasem nowy obiekt wydzielano wraz z najbliższym otoczeniem jako niezależną działkę ewidencyjną. Tak stało się np. w Luberadzu, słynnym mazowieckim parku z nietypowym klasycystycznym pałacem, gdzie z historycznego obszaru rezydencji wydzielono dużą działkę $\mathrm{z}$ budynkiem dawnego internatu, niszcząc integralność zabytku.

Zły lub średni stan zachowania znacznej liczby polskich parków i ogrodów zabytkowych powoduje konieczność prowadzenia prac konserwatorskich lub działań restauratorskich. Aby $\mathrm{w}$ trakcie tego procesu, a zwłaszcza $\mathrm{w}$ trakcie prac restauratorskich, zachować autentyczność oraz integralność zabytku, prace te muszą zostać oparte na naukowych podstawach (zgodnie z zaleceniem Karty Florenckiej, art. 15). Kompleksowe badania, w tym kwerendy archiwalne, badania z zakresu archeologii ogrodowej, analizy porównawcze coraz częściej poprzedzają prace restauratorskie. Impulsem i pewnym wzorcem dla tego typu podejścia w ogrodach zabytkowych stały się przeprowadzone w latach 70. XX wieku prace restauratorskie w holenderskim ogrodzie Het Loo. Metodę tę w kolejnych dziesięcioleciach wdrożono w ogrodach Hampton Court w Wielkiej Brytanii, w Wersalu oraz w niektórych ogrodach austriackich i niemieckich. W Polsce kompleksowe badania poprzedzające prace restauratorskie przeprowadzono w latach 90 . XX wieku i po roku 2000 w Ogrodzie Wilanowskim oraz w Ogrodzie Branickich w Białymstoku. Wnioski z nich posłużyły do określania historycznej formy przestrzennej badanych ogrodów, rozpoznania elementów ich kompozycji: układu drogowego, szaty roślinnej i zasad jej rozplanowania, elementów małej architektury i wystroju rzeźbiarskiego, elementów wodnych.

W karcie florenckiej (art. 9) wskazano, że autentyczność ogrodu uzależniona jest od zachowania historycznego doboru roślin. Warunek ten, $\mathrm{z}$ wielu względów bywa niekiedy trudny do spełnienia. Część odmian roślin przestaje być z czasem produkowana i jest zastępowana nowymi, lepiej dostosowanymi do lokalnych warunków klimatycznych i bardziej odpornymi na choroby (jest to np. przypadek wielu odmian historycznych róż). Współczesne odmiany bywają też dużo bardziej spektakularne niż historyczne - w związku z tym np. odtwarzając regularną część ogrodu w Hampton Court, zdecydowano się na bardzo szeroki zakres interpretacji tego zabytku, aby zwiedzający mogli zrozumieć, dlaczego oparte na historycznych wzorcach nasadzenia są tak skromne. Niektóre gatunki, jak np. kasztanowce białe Aesculus hippocastanum czy bukszpan wieczniezielony Buxus sempervirens są atakowane przez szkodniki, których populacji nie udało się dotychczas ograniczyć. W wielu polskich parkach kasztanowce zaatakowane przez szrotówka kasztanowcowiaczka praktycznie już od połowy lata pozbawione są liści. Jest to niezwykle trudna sytuacja, ponieważ kasztanowiec biały to jedno z najpowszechniej stosowanych drzew parkowych i alejowych w Polsce (zwłaszcza w parkach dziewiętnastowiecznych i z 1. poł. XX wieku). 
Zkolei masowe zamieranie bukszpanu powoduje ogromne zagrożenie dla wszystkich regularnych założeń ogrodowych. W związku $\mathrm{z}$ tą sytuacją we francuskim ogrodzie w Vaux-le-Vicomte zdecydowano się na usunięcie ornamentów bukszpanowych i zastąpienie ich współczesną instalacją artystyczną wykonaną z metalu. Natomiast bukszpan na parterach w polskich ogrodach regularnych, np. w Ogrodzie Wilanowskim czy w Ogrodzie Branickich w Białymstoku, był w ostatnich latach kilkukrotnie partiami wymieniany.

Pewne rośliny stają się też okresowo bardzo modne i są nadużywane, np. srebrne świerki Picea pungens „Glauca” czy wiele różnych odmian płożących jałowców (moda na nie zaczęła się jeszcze w okresie międzywojennym). Ich obecność w wielu ogrodach nie znajduje historycznego uzasadnienia (np. w Bychowie na Pomorzu, gdzie srebrne świerki zasłoniły ogrodową elewację dworu; czy na rabatach przy dworze w Chamsku, gdzie dominują płożące jałowce).

Autentyzm zabytkowych ogrodów budują również elementy historycznej małej architektury oraz rzeźby ogrodowe. Tego typu elementy przetrwały w niewielu parkach. Zazwyczaj są to ogrodzenia, niekiedy pawilony ogrodowe, mostki, pergole, tarasy ogrodowe z balustradami i schodami, fontanny i kaskady, bardzo rzadko rzeźby parkowe, groty, historyczne ławki, elementy historycznego oświetlenia. Unikatowość elementów tego typu powoduje, że powinny być one bezwzględnie chronione i odpowiednio eksponowane. Za szczególnie niebezpieczne należy uznać likwidowanie ogrodzeń historycznych parków i ogrodów, co potencjalnie może stanowić impuls do wprowadzania w ich granice nowych funkcji (tak stało się na obrzeżach pozbawionego ogrodzenia Ogrodu Saskiego w Warszawie, gdzie od północy urządzono parkingi).

Skromny zasób historycznej małej architektury i detalu rzeźbiarskiego powoduje, że jest ona masowo uzupełniana nowymi elementami. Niekiedy powielają one historyczne rozwiązania (np. ławki w Łazienkach Królewskich i Ogrodzie Krasińskich, donice na drzewka oranżeriowe w Wilanowie i Ogrodzie Branickich w Białymstoku, fontanny w Ogrodzie Branickich), czasami stanowią ich swobodną, współczesną interpretację (np. częśćrzeźb w Ogrodzie Branickich, donice w ogrodzie Zamku Królewskiego w Warszawie, przeskalowane w stosunku do oryginalnych). Czasami też są to elementy całkowicie nowe - jak np. fontanna na osi warszawskiego Zamku Królewskiego czy też ławki, mostek, pergole w parku w Żelazowej Woli, a wśród przykładów zagranicznych nowa aranżacja Bosquet du Théâtre d'Eau w Wersalu ${ }^{11}$. Nowe elementy mogą stanowić pewną wartość dodaną, ale niekiedy też degradują kompozycję ogrodową i świadczą o braku znajomości zarówno historycznego, jak i współczesnego warsztatu projektowego. Przykładami niefortunnych współczesnych rozwiązań w parkach zabytkowych są np. masywne obrzeża parterów z piaskowca w Międzyrzecu Podlaskim oraz tamtejsza altana, obrzeża ścieżek z piaskowca w parku w Białej Podlaskiej, mostek „chiński” w parku przy Muzeum Ziemiaństwa w Dąbrowie koło Siedlec.

${ }^{11}$ Lamy G., Rok Le Nôtre’a w Pałacu Wersalskim, Ochrona Zabytków, 69/1 (268), 2016, ss, 243-258. 


\section{Dorota Sikora}

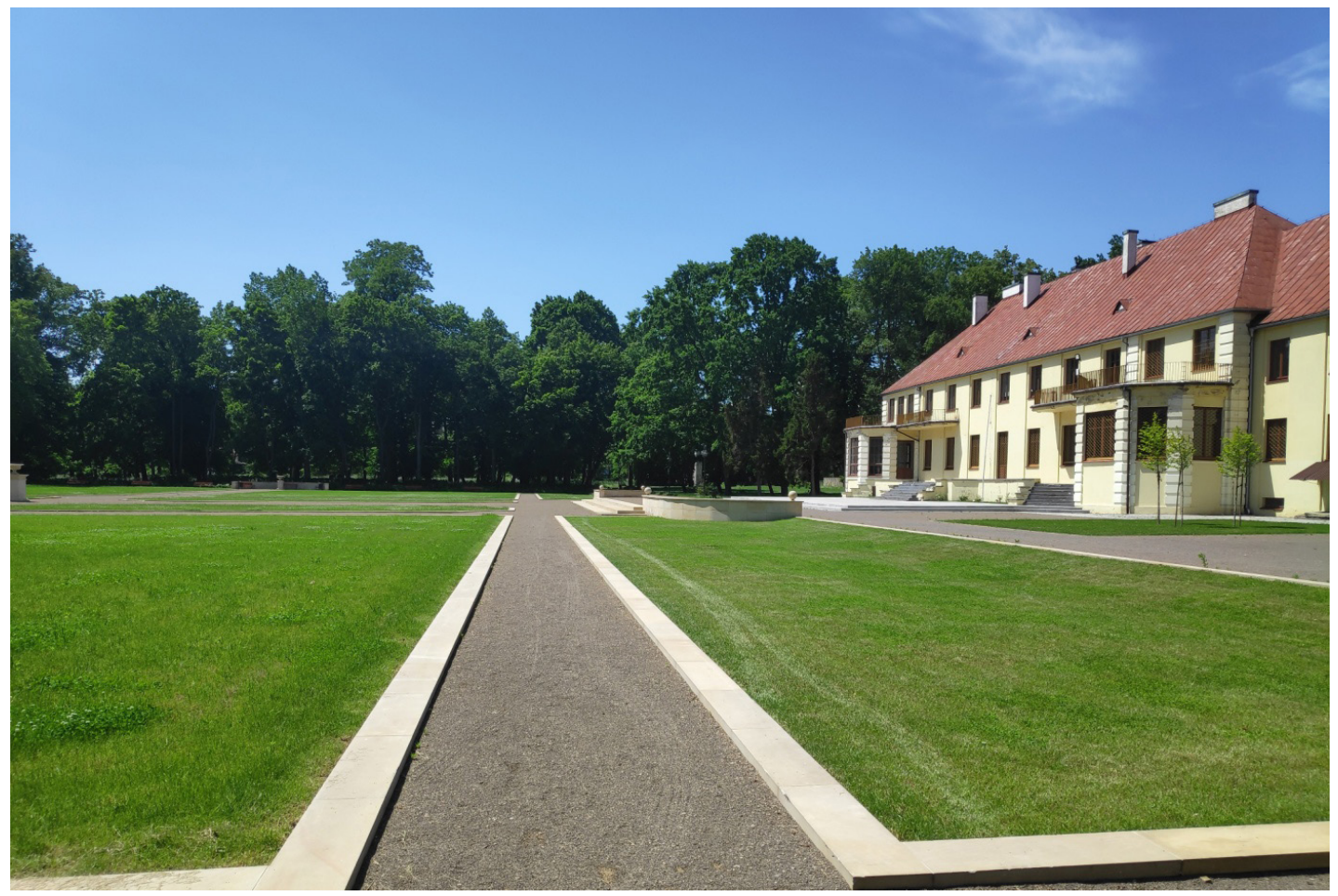

Il. 6. Park w Międzyrzecu Podlaskim. Obrzeża parterów wykonane z piaskowca - nowe rozwiązanie niemające uzasadnienia historycznego. Fot. D. Sikora, 2020

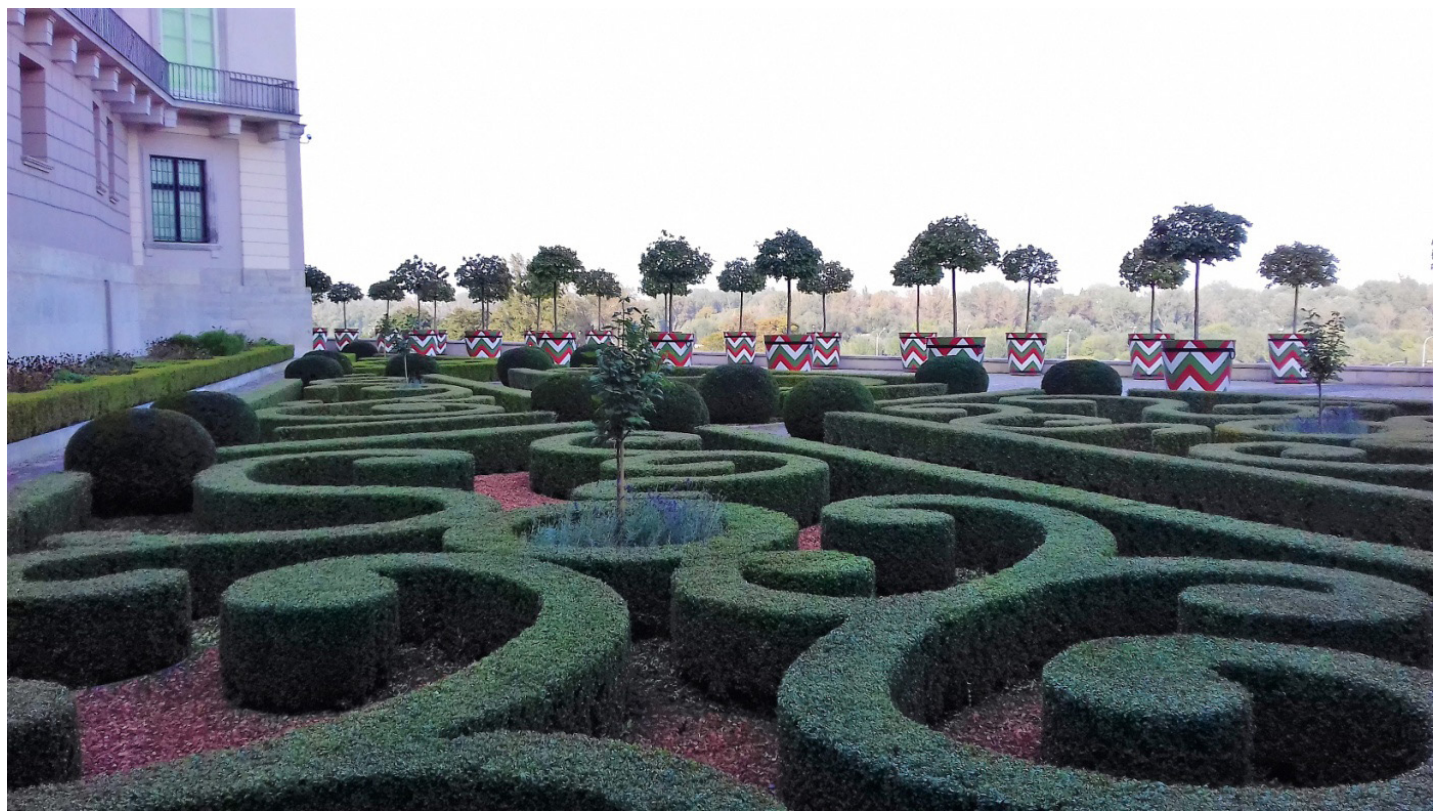

Il. 7. Donice w ogrodzie Zamku Królewskiego w Warszawie - współczesny element inspirowany rozwiązaniami historycznymi. Fot. D. Sikora, 2019 


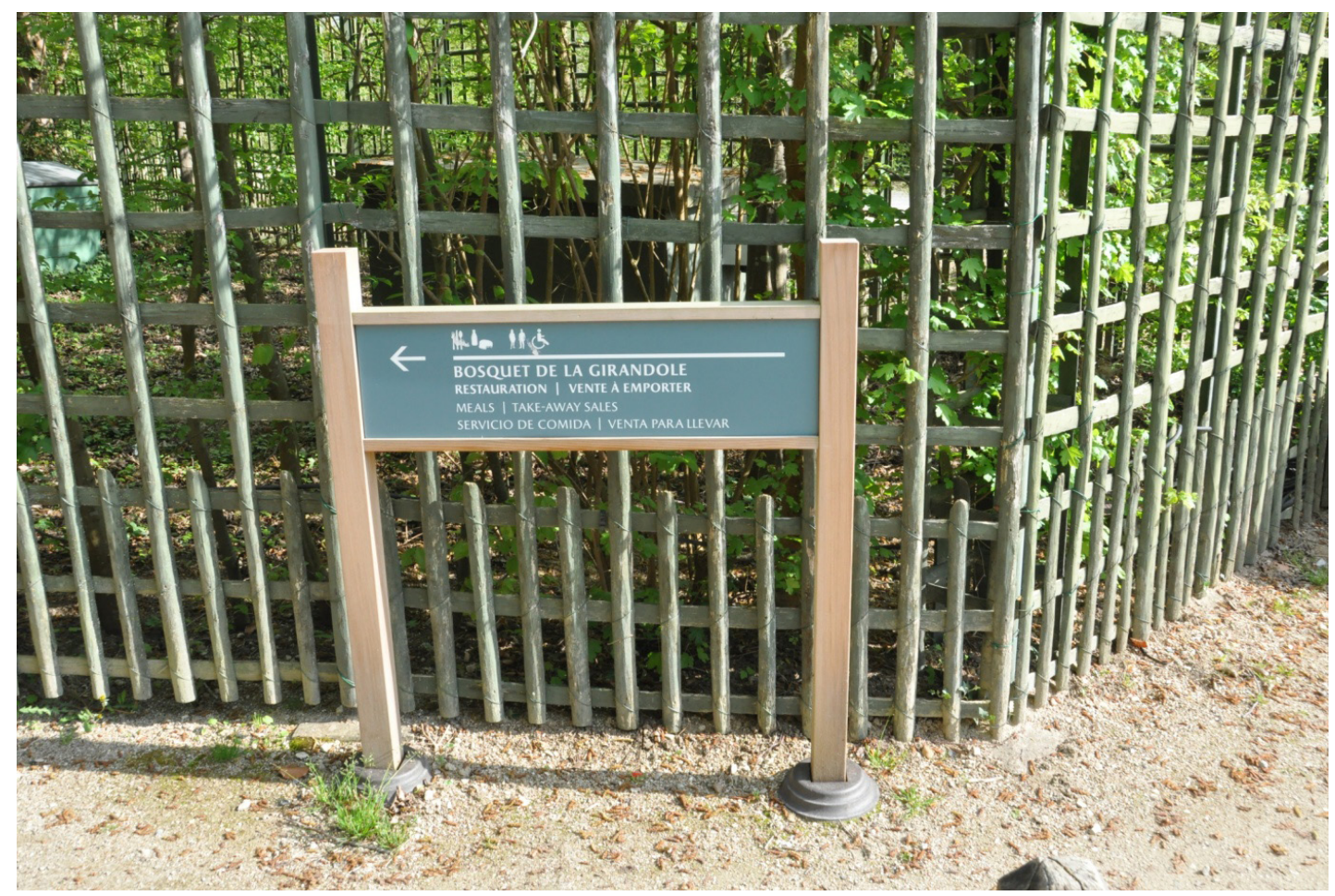

Il. 8. Współczesna infrastruktura turystyczna Ogrodu Wersalskiego - prosta w formie i utrzymana w ciemnozielonym, neutralnym kolorze. Fot. D. Sikora, 2019

Warto $\mathrm{w}$ tym miejscu przywołać dobrą zasadę zastosowaną w ogrodach Wersalu: większość historycznych elementów małej architektury została tu poddana pieczołowitej konserwacji, część została wiernie zrekonstruowana, natomiast elementy współczesne, których obecność wynika z konieczności dostosowania tego obiektu do potrzeb ruchu turystycznego, zostały zaprojektowane w formach jak najbardziej neutralnych. Nie są też one na stałe połączone z podłożem, są w większości wykonane z drewna i utrzymane w kolorystyce ciemnej zieleni, mało widocznej na tle zadrzewień ogrodu. Dzięki takiemu podejściu nie wpływają degradująco na przestrzeń zabytkowego ogrodu.

Ogromną wartością i czynnikiem wzmacniającym autentyczność zabytkowych ogrodów jest przetrwanie ich historycznego otoczenia krajobrazowego. Niestety dynamika zmian w tym względzie stale się zwiększa ${ }^{12}$. W dobie z jednej strony silnej urbanizacji, z drugiej zaś wygaszania na wielu terenach tradycyjnych form uprawy ziemi, niezwykle trudno jest zachować historyczny kontekst krajobrazowy, który dla wielu ziemiańskich rezydencji stanowiły właśnie pola uprawne i łąki. Jest to szczególnie zauważalne w środkowej części Europy, gdzie aż po czasy II wojny światowej obecna była tradycyjna kultura ziemiańska oparta na ekstensywnej uprawie roli ${ }^{13}$.

\footnotetext{
${ }^{12}$ Rędzińska K., Szulczewska B., Landscape change as perceived by its residents: A case study of Wilanów West in Warsaw, Land Use Policy, 85, 2019, ss. 259-270.

${ }^{13}$ Nurme S., Kotval Z., Nutt N., Hiob, M., Salmistu S., Baroque manorial cores and the landscape, Journal of Cultural Heritage. Management and Sustainable Development, 4 (2), 2014, ss. 166-183.
} 
Problem z zachowaniem historycznego kontekstu krajobrazowego nie dotyczy wyłącznie parków i ogrodów zlokalizowanych na terenach niezurbanizowanych. Również w granicach miast zachodzą $\mathrm{w}$ otoczeniu zabytkowych parków szybkie zmiany. Ich symbolem może być jeden z kluczowych widoków z Łazienek Królewskich w kierunku Belwederu i otaczającego krajobrazu, który kilka lat temu uległ degradacji na skutek budowy w tle Belwederu centrum handlowo-biurowego.

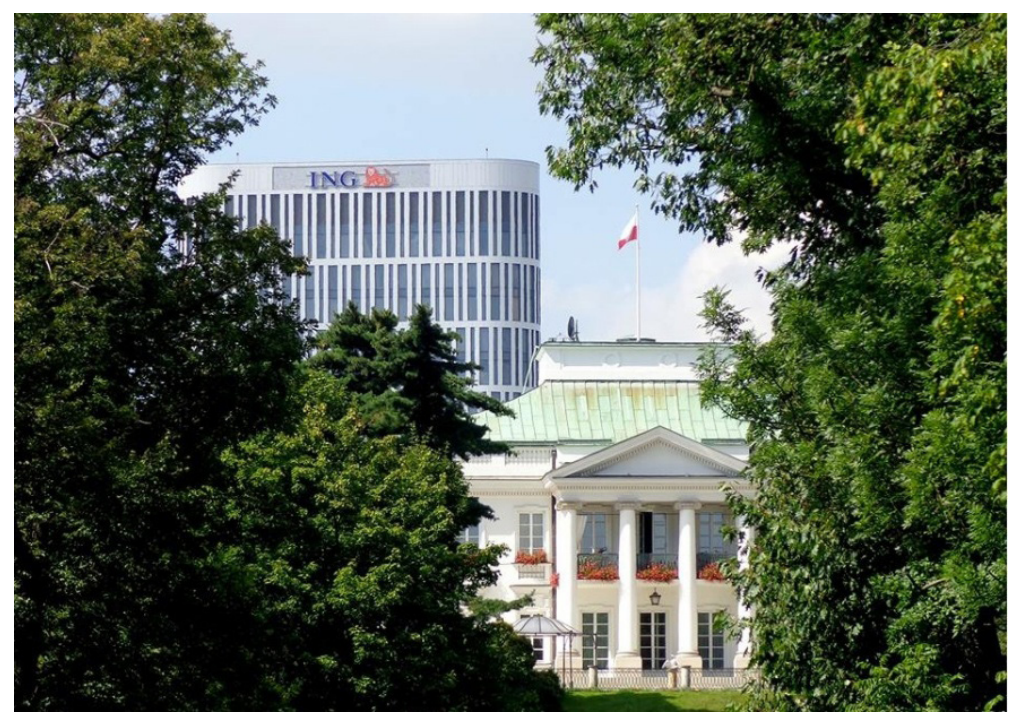

Il. 9. Widok z Łazienek Królewskich w kierunku Belwederu. Jego autentyzm zniszczył współczesny budynek handlowo-biurowy. Fot. D. Sikora, 2020

Z problemami zachowania kontekstu krajobrazowego historycznych rezydencji mierzą się też inne kraje: przykładowo kilka założeń dworsko-parkowych i ich otoczenie znajdujących się w granicach Helsinek narażonych jest na silne przekształcenia $\mathrm{z}$ powodu braku stosownych procedur planistycznych i ochronnych ${ }^{14}$, natomiast $\mathrm{w}$ hiszpańskim Aranjuez reprezentacyjny dojazd w postaci „gęsiej stopki” do królewskiej rezydencji i jej ogrodów zniszczyła wzniesiona w bliskim sąsiedztwie stacja kolejowa i budynki magazynowe ${ }^{15}$. Na tym tle pozytywnym przykładem ochrony historycznego kontekstu krajobrazowego zespołu pałacowo-ogrodowego jest niemieckie Wörlitz, gdzie w imię zachowania autentyzmu otaczającego krajobrazu rolnego posunięto się nawet do wyburzenia odległych o kilka kilometrów kominów fabrycznych elektrowni Vockerode. Należy jednak w tym miejscu zauważyć, że założenie pałacowo-ogrodowe Wörlitz jest wpisane na Listę światowego dziedzictwa, a obecność jego strefy buforowej pomaga chronić otaczający krajobraz ${ }^{16}$. Wydaje się, że w tej sytuacji, zarówno w Polsce, jak i w wielu innych krajach, jedynie wprowadzenie

\footnotetext{
${ }^{14}$ Hautamäki R., The encounter between manor and city: manor landscapes in urban planning in Helsinki, Nordic Journal of Architectural Research, 1, 2020, ss. 73-98.

${ }^{15}$ Aníbarro M. A., Ibáñez J., Gazapo, D. I., Aranjuez, a Cultural Landscape in a Process of Revitalisation: The Recovery of the Raso de la Estrella, Journal of Landscape Architecture, 3 (2), 2008, ss. 54-67.

${ }^{16}$ Tenzer H., The Garden Kingdom of Dessau-Wörlitz as an Example for the Management of a Historical Monument, Proceedings of the Fábos Conference on Landscape and Greenway Planning: Vol. 5: No. 1, 2016, ss. 121-130.
} 
silniejszych mechanizmów ochrony kontekstu krajobrazowego zabytków może przyczynić się do zachowania ich autentyzmu - również w aspekcie powiązań funkcjonalnych i kompozycyjnych z krajobrazem otaczającym. Obecnie w Polsce, według danych Narodowego Instytutu Dziedzictwa, liczba zabytkowych parków, których otoczenie jest chronione wpisem do rejestru zabytków wynosi zaledwie 186, co stanowi 2,7\% zasobu wszystkich zabytkowych obiektów z tej kategorii.

\section{Społeczne oczekiwania wobec historycznych parków, ogrodów i innych form zaprojektowanej zieleni}

Istotnym czynnikiem wpływającym na możliwość dalszego trwania, ochrony i konserwacji historycznych terenów zieleni są funkcje, jakie przypisuje im społeczeństwo. Społeczne oczekiwania, potrzeby i aspiracje względem jakiegoś historycznego obiektu czy obszaru oraz świadomość jego wartości przekładają się na chęć podejmowania w nim określonych działań ochronnych i konserwatorskich lub też na brak społecznej akceptacji dla działań niszczących.

Wielu współczesnych użytkowników i zarządców postrzega wartości terenów zieleni w kontekście możliwości realizowania przez nie społecznie ważnych usług ekosystemowych ${ }^{17}$ : siedliskowych, zaopatrujących, regulacyjnych i kulturowych. Wśród tych ostatnich wymieniane są między innymi: rekreacja, turystyka, zaspokajanie potrzeb estetycznych, edukacyjnych, kształtowanie relacji społecznych i więzi z miejscem (budowanie tożsamości lokalnej), pełnienie funkcji źródła inspiracji kulturowej i intelektualnej. Wydaje się, że do realizacji tej ostatniej grupy usług ekosystemowych zabytkowe tereny zieleni są szczególnie predestynowane.

Konieczność powiązania ochrony i konserwacji zabytku z jego użytkowaniem na cele użyteczne społecznie podkreślono w karcie weneckiej (art. 5), zastrzegając jednak, że użytkowanie takie jest pożądane, nie może wszakże pociągać za sobą zmian układu bądź wystroju (...) Są to granice, w jakich należy pojmować i można dopuszczać zagospodarowanie, wymagane przez ewolucję zwyczajów i obyczajów.

W świetle powyższego należy stwierdzić, że osadzenie ochrony i zachowania wartości zabytkowych parków, ogrodów oraz innych form zaprojektowanej zieleni w szerszym kontekście wartości, odpowiadających na lokalne i ponadlokalne potrzeby społeczne, będzie sprzyjało większej skuteczności ich ochrony i uzasadniało konieczność ponoszenia kosztów związanych $\mathrm{z}$ ich konserwacją. Pomoże również tak programować działania adaptacyjne do współczesnych potrzeb, aby szanowały wartości, uznawane za społecznie ważne.

${ }^{17}$ Millennium Ecosystem Assessment, Opracowanie na zlecenie Organizacji Narodów Zjednoczonych, 2005, ss. 40-45. 


\section{Podsumowanie}

Co dziesiąty polski zabytek to teren zieleni - w większości przypadków park lub ogród. Ogromne znaczenie, jakie zabytki tej kategorii mają dla tożsamości polskiego krajobrazu, wynikające z ich wartości historycznych, artystycznych i naukowych, powoduje, że powinny stanowić przedmiot pieczołowitej ochrony, pielęgnacji, a w miarę potrzeb również konserwacji czy restauracji. Nie do przecenienia są również ich wartości użytkowe i przyrodnicze, tak istotne zwłaszcza dla mieszkańców współczesnych miast.

Przeanalizowany pokrótce w niniejszym artykule zasób polskich parków i ogrodów zabytkowych oraz określenie jego najczęstszych zagrożeń posłużyły za punkt wyjścia do wskazania obszarów, w których w pierwszej kolejności powinno się podjąć działania na rzecz poprawy stanu tej części polskiego dziedzictwa kulturowego oraz warunków, jakie powinny spełniać współczesne interwencje. Są to:

- Wzmocnienie świadomości społecznej co do wartości kulturowych tej grupy zabytków oraz co do korzyści, jakie dostarcza współczesnym społeczeństwom ta grupa zabytków.

- Aktualizacja stanu wiedzy o zasobie zabytkowych parków i ogrodów oraz o stanie tego zasobu.

- Propagowanie dobrych praktyk w zakresie pielęgnacji, konserwacji i restauracji zabytkowych parków i ogrodów.

- Zapobieganie podziałom własnościowym historycznych parków i ogrodów, dbałość o ich integralność terytorialną.

- Zapobieganie wprowadzaniu trwałych przekształceń w granicach zabytkowych parków i ogrodów, degradujących substancję zabytkową i historyczny układ przestrzenny.

- Warunkowanie możliwości wprowadzania nowych form rekreacji w granice parków i ogrodów zabytkowych brakiem ich negatywnego oddziaływania na substancję zabytkową i historyczny układ przestrzenny.

- Podjęcie działań na rzecz skuteczniejszej ochrony kontekstu krajobrazowego zabytkowych parków i ogrodów.

- Podjęcie działań na rzecz zrównoważonego traktowania wartości kulturowych i przyrodniczych parków i ogrodów zabytkowych - dotyczy to szczególnie obiektów objętych prawnymi formami ochrony przyrodniczej (np. w formie rezerwatów przyrody), gdzie prowadzenie prac pielęgnacyjnych czy konserwatorskich jest znacznie utrudnione. 
Parki, ogrody oraz inne formy komponowanej zieleni - warunki brzegowe współczesnych interwencji

\section{Bibliografia}

Aníbarro M. A., Ibáñez, J., Gazapo D. I., Aranjuez, a Cultural Landscape in a Process of Revitalisation: The Recovery of the Raso de la Estrella, Journal of Landscape Architecture, 3 (2), 2008.

Hautamäki, R., The encounter between manor and city: manor landscapes in urban planning in Helsinki, Nordic Journal of Architectural Research, 1, 2020.

Jagiełło M. , Do We Need a New Florence Charter? The Importance of Authenticity for the Maintenance of Historic Gardens and Other Historic Greenery Layouts in the Context of Source Research (Past) and Taking into Account the Implementation of the Sustainable Development Idea (Future). Sustainability, 13(9), 4900, 2021, https://doi.org/10.3390/su13094900

Karta Ateńska, Postanowienia Konferencji w Atenach, 1931.

Karta Florencka - Międzynarodowa Karta Ogrodów IFLA, ICOMOS, 1981.

Karta Wenecka - Postanowienia i Uchwaly II Międzynarodowego Kongresu Architektów i Techników Zabytków w Wenecji w 1964 r., 1964.

Krasicki I. , Listy o ogrodach, [w:] Dzieła proza Ignacego Krasickiego, edycja nowa i zupetna przez Fr. Dmochowskiego, t. V. Warszawa, 1803.

Lamy G., Rok Le Nôtre’a w Pałacu Wersalskim, Ochrona Zabytków, 69/1 (268), 2016.

Majdecki L., Ochrona i konserwacja zabytkowych założeń ogrodowych, Warszawa: PWN, 1993.

Michałowski A., Rewaloryzacja ogrodu Jana Klemensa Branickiego w Białymstoku na tle działań konserwatorskich w ogrodach historycznych Europy, [w:] Parki i ogrody zabytkowe, ochrona i konserwacja. Ogród Branickich w Białymstoku, historia rewaloryzacji, Białystok: Urząd Miejski w Białymstoku, 2010.

Millennium Ecosystem Assessment, Opracowanie na zlecenie Organizacji Narodów Zjednoczonych, 2005.

Nurme S., Kotval Z., Nutt N., Hiob M., Salmistu S., Baroque manorial cores and the landscape, Journal of Cultural Heritage. Management and Sustainable Development, 4 (2), 2014.

Rędzińska K., Szulczewska B., Landscape change as perceived by its residents: A case study of Wilanów West in Warsaw, Land Use Policy, 85, 2019.

Rozbicka M. (red.), Raport o stanie zabytków nieruchomych w Polsce. Zabytki wpisane do rejestru zabytków (księgi rejestru A i C), Warszawa: Narodowy Instytut Dziedzictwa, 2017.

Sikora D., Nowe tendencje w obiektach zieleni zabytkowej - na przykładzie Ogrodu Wersalskiego, Teka Komisji Urbanistyki i Architektury PAN Oddział w Krakowie, t. XLV, 2017.

Sikora D., Kaczyńska M., Landscape in transition: the case of the Royal Axis in Wilanów, Journal of Urban Design, 26. 4, 2021, DOI: 10.1080/13574809.2020.1861931 
Tenzer H., The Garden Kingdom of Dessau-Wörlitz as an Example for the Management of a Historical Monument, Proceedings of the Fábos Conference on Landscape and Greenway Planning: Vol. 5: No. 1, 2016.

Ustawa z dnia 23 lipca 2003 r. o ochronie zabytków i opiece nad zabytkami, Dz.U. 2003 nr 162 poz. 1568.

Zachariasz A., Zabytkowe ogrody - problemy rewaloryzacji, utrzymania i zarządzania w świetle zaleceń Karty Florenckiej, Prace Komisji Krajobrazu Kulturowego, 10, 2008. 